\title{
The effects of migrant remittances on population- environment dynamics in migrant origin areas: international migration, fertility, and consumption in highland Guatemala
}

\author{
Jason Davis • David Lopez-Carr
}

Published online: 22 October 2010

(C) The Author(s) 2010. This article is published with open access at Springerlink.com

\begin{abstract}
International migration impacts origin regions in many ways. As examples, remittances from distant migrants may alter consumption patterns within sending communities, while exposure to different cultural norms may alter other behaviors. This paper combines these insights to offer a unique lens on migration's environmental impact. From an environmental perspective, we ask the following question: is the likely rise in consumption brought about by remittances counterbalanced by a reduction in fertility in migrant households following exposure to lower fertility cultures? Based on ethnographic case studies in two western highland Guatemalan communities, we argue that the near-term rise in consumption due to remittances is not counterbalanced by rapid decline in migrant household fertility. However, over time, the environmental cost of consumption may be mitigated at the community level through diffusion of contraception and family planning norms yielding lower family size.
\end{abstract}

Keywords Migration - Remittances · Population · Consumption · Fertility · Guatemala · Latin America

\section{Introduction}

The dynamics surrounding remitted income-influences on receiving-community development and migrant household lifestyle, for example-are receiving considerable attention from social scientists, economists, national governments, and

J. Davis - D. Lopez-Carr

Department of Geography, University of California, Santa Barbara,

1832 Ellison Hall, Santa Barbara, CA 93106-4060, USA

J. Davis ( $\square)$

161 Dolores Street \#4, San Francisco, CA 94103, USA

e-mail: jason_davis@umail.ucsb.edu 
multinational development agencies. Investigators have, as examples, studied the relationships between remittances and poverty alleviation (Adams 2004, 2006), the promotion of local development (Taylor 1999), the spurring of business investment (Durand et al. 1996a), the altering of agricultural practices (Taylor et al. 2006; Gray 2009), and the advancement of education (Kandel and Kao 2001) and health (Kanaiaupuni and Donato 1999). What is often absent in these studies, however, are the potential countervailing influences of migration processes that facilitate remittance transfers. Combined, international migration and the resulting remittances provide an opportunity to observe how individuals and households from poor, developing regions respond both to boosts in income and to immersion into different cultures.

One critical area of interest is how individuals from developing areas impact the environment vis-à-vis material consumption and population change as they become more affluent and gain exposure to cultures with lower fertility dynamics. ${ }^{1}$ While it is likely a foregone conclusion that a rise in wealth will lead to a corresponding rise in material consumption (Kates 2000), it remains an open question how migrant households spending patterns change over time as they gain more experience abroad and they remit more income. Similarly, fertility patterns may also change-possibly in a downward direction - as international migrants often gain exposure to cultures with different fertility norms leading to changes in their fertility belief systems. If lower fertility behaviors in migrant destinations are adopted, will fertility fall to a sufficient level to counterbalance a certain rise in per capita consumption-i.e., fewer individuals consuming at higher rates? To gain some insight into these questions, we initiated an ethnographic case study in two rural western highland Guatemalan communities to determine whether return international migrants change both their material consumption and fertility patterns. Based on our results, it appears that successful migration by poor Guatemalans has a net negative impact on the environment related to a rise in resource consumption. Specifically, fertility reductions due to the adoption and diffusion of US fertility norms appear unlikely to ameliorate the immediate rise in individual material consumption attributable to remittance-induced affluence. This finding provides an indication of how population and consumption dynamics may play out in the future as rural areas of emergent economies slowly gain affluence in an era of globalization.

The questions raised above are not merely academic; they are core to humanenvironment sustainability. Just over ten years ago, the planet's wealthiest countries-constituting approximately $20 \%$ of its human population-accounted for $86 \%$ of its annual natural resource use (UN 1998). Today, while individuals in the most (highest) developed countries (HDCs) have not dropped their resource consumption in the last 10 years, lesser-developed countries (LDCs) such as China and India are quickly catching up. Currently, LDCs account for approximately $60 \%$ of the planet's annual natural resource use compared with $40 \%$ in HDCs (WWF 2008). Another concerning factor to environmental security is population growthespecially in rapidly developing economies. Currently, populations in LDCs are

\footnotetext{
${ }^{1}$ Two other population dynamics not covered by this investigation are mortality and population momentum.
} 
projected to double in 53 years compared with 240 years in HDCs (UN 2009). Population growth in LDCs will account for virtually all future population growth on the planet (PRB 2009), and the total world population is expected to surpass seven billion in 2011.

Much like global climate change, the impacts of human population and consumption growth are complex, ubiquitous, and difficult to grasp in connection with the environment. Because individuals exact environmental harm both locally and globally, it is nearly impossible to make a direct causal linkage between population/consumption change and a concomitant change in pollution levels or on-the-ground land use change. Many studies have proffered links between population growth and deforestation (Allen and Barnes 1985; Rosero-Bixby and Palloni 1998; Mather and Needle 2000). However, most of these endeavors are complicated by other underlying forces including economic and political factors (Geist and Lambin 2002; Carr 2004). Consumption of natural resources, on the other hand, is even more abstract as multiple environmental harms may emerge during a product's (or its residual parts) lifetime. As such, to adequately characterize environmental ills associated with the consumption of just one product requires a thorough accounting of numerous physical and chemical phases (natural resource extraction, processing, shipping, and disposal).

Nevertheless, population and consumption dynamics are critical to our understanding of environmental change. Considering concepts of ecological footprint or carrying capacity, our planet represents a fixed space with a finite supply of renewable natural resources that are increasingly being exhausted as more humans both populate the planet and elevate their use of these resources (Daily and Ehrlich 1992; Rees and Wackernagel 1994). Kitzes et al. (2008) found that in 2002, the rate of renewable natural resource consumption by humankind stood at $120 \%$ of the planet's ability to regenerate these resources-meaning instead of consuming exactly what was generated for that year, humans were tapping into natural resource reserves and jeopardizing the ability of the planet to produce these resources in the future.

When one starts to devolve from the macro- to the micro-global economy, large segments of the world's immigrant population are deeply rooted in emergent economies. Due to resource inequity and scarcity among other push factors, many poorer households use migration as a means to diversify income streams, alleviate perceived disparities in wealth, and fund entrepreneurial ventures (Massey et al. 1993; Durand et al. 1996a; Taylor 1999). The emigration rate for all LDCs stood at 3.9\% between 2000 and 2002, while Latin America and the Caribbean supported a $5.5 \%$ emigration rate (UN 2009). Compared with Mexico, migration between Guatemala and the United States is relatively young. Much of its inception can be unfortunately attributed to forced migration during 36 years of civil war (Brockett 1988; Morrison 1993; Lovell 1995; Moran-Taylor 2008) that ended with the signing of peace accords in 1996 (Manz 2004). Over the last 15-20 years, a fragile peace has settled in the country, and many forced migrants have returned to their native homes (House 1999). However, and perhaps facilitated by the economic turmoil that remained after the civil war (Smith 2006) and the opportunities that some forced migrants were exposed to during earlier migrations, many Guatemalans are now 
predominately using international migration and remittance transfer as a vehicle to alleviate poverty, enhance social status, and provide better opportunities for themselves and their children (Adams 2004; Adams and Page 2005; Taylor et al. 2006). According to the International Organization for Migration, approximately $11 \%$ (1.5 million) of Guatemala's population was living abroad in 2008, $97 \%$ of which reside in the USA (IOM 2008). This contrasts with just under 500,000 Guatemalans living abroad in 1996-the year the peace accords were signed. And, while global remittance flows have more than doubled from $\$ 132$ to $\$ 337$ billion between 2000 and 2007, they are also equivalent to more than $10 \%$ of the GDPs of 24 developing nations including Guatemala-10.3\% (IMF 2008).

While an emerging literature has begun to explore the remittance impacts on land use and land cover change in migrant-sending communities, much less is known about other potential environmental outcomes from remittance flows. Toward addressing this gap, we present a case study from the Guatemalan highlands, which investigates potential environmental impacts conditioned by migration and remittances: fertility and consumption. The following conceptual framework section summarizes the relevant literature concerning the importance of population growth and resource consumption as indicators of environmental change both globally and locally in rural Latin American communities and proposes a theoretical construct for framing household responses to remittances. Following a description of research methods, we describe both population (fertility) and resource consumption change dynamics in response to international migration and remittance flows in select rural Guatemalan western highland communities. A summary of case study findings on fertility and consumption responses to migration and remittances follows, and the paper concludes with the consideration of how an integrative perspective on migration, remittances, and rural household responses can guide future research and policy.

\section{Conceptual framework}

Research relating migration to environmental change has traditionally investigated displacement, particularly refugee flows (e.g., Kane 1995). Less research exists on migration compelled by chronic environmental deterioration (Lonergan 1998; Carr 2009). Recent exceptions include work on environmental causes of global urbanization (Adamo 2010), climatic change and migration from Oceania (i.e., Moore and Smith 1995), and migration in response to drought (e.g., Findley 1994) and HIV/AIDS (Camlin et al. 2010) in sub-Saharan Africa. Similarly, research has examined how people respond to changing environmental conditions (e.g., Bilsborrow 1987; Panayatou 1994), particularly vis-à-vis agricultural intensification or extensification (Turner and Ali 1996; Moran 1993; Carr 2008). But little research to date has investigated potential household responses to remittance influxes with a focus on environmental impacts. An exception is the emerging work on land use and land cover change (LUCC) facilitated by remittances (e.g., Jokisch 2002; Taylor et al. 2006; Davis 2006; Gray 2009).

While the LUCC investigations represent a compelling research avenue, there are numerous other ways that international migration of poorer migrants can influence 
the environment in sending/receiving communities as well as globally. From a household perspective, the separation of population and LUCC from migration and remittances belies the inherent interconnections between them. Do households make decisions to regulate fertility, change consumption patterns, or modify land use under the same types of contextual factors as they do to migrate in the first place? Or are the processes fundamentally distinct? Fertility regulation, consumption dynamics, and LUCC are not ultimate outcomes, nor is migration. Building on multiphasic response theory, migration is often the last response to population and resource pressures in origin communities once socio-economic and fertility options are exhausted (Davis 1963; Bilsborrow 1987; Carr et al. 2009).

\section{Beyond multi-phasic response theory: a conceptual model of remittances, consumption, and fertility}

Following Fig. 1, a large LUCC literature explores agricultural intensification and expansion, as noted in the dotted arrow from "Land Management" to "Agricultural Extensification or Intensification" (Carr et al. 2006; Geist and Lambin 2002). Population scholars focus on links between "Household Responses", "Fertility Regulation", and "Migration"; economists often investigate "Household Responses" and "Off-farm Labor." Although researchers often separate these themes into disciplinary categories, households in the real world do not fit neatly into such clusters. Households may respond in one or more ways simultaneously or sequentially, in response to demographic, political-economic, socio-economic, and ecological dynamics at international, national, and/or local scales. Changing consumption, land, labor, capital investments, or fertility may result from a host of "pushes" or catalysts. Following the thick arrows in Fig. 1, the iteration examined here focuses on household decisions to regulate fertility and/or alter consumption patterns following the decision of a household member to out-migrate and ultimately remit money back to the origin household. Once a decision, or suite of decisions, has been made, other responses follow sequentially (and also potentially occur simultaneously), and the household once again is faced with external structures and processes that shape subsequent decision making (as illustrated at the bottom of Fig. 1 where the arrow returns to the diagram's top).

\section{Migration, remittances, and fertility}

Numerous investigations have analyzed how the fertility patterns of migrant women change upon arrival in countries with lower fertility norms compared to their communities of origin. However, fewer studies have been conducted to determine how migrant fertility patterns are influenced by migration experiences and remittances upon returning to migrant origins. One line of argument concerning receiving country effects on future fertility is a combination of the migrant adopting the fertility norms of the receiving country and diffusing newly begotten knowledge to others upon return to origin (Lindstrom 2003; Lindstrom and Saucedo 2002). Another theory, the quantity/quality tradeoff, takes a more economic angle to describe fertility change (Becker 1992). This perspective argues that as households 


\section{Rural Household Responses to Remittances}

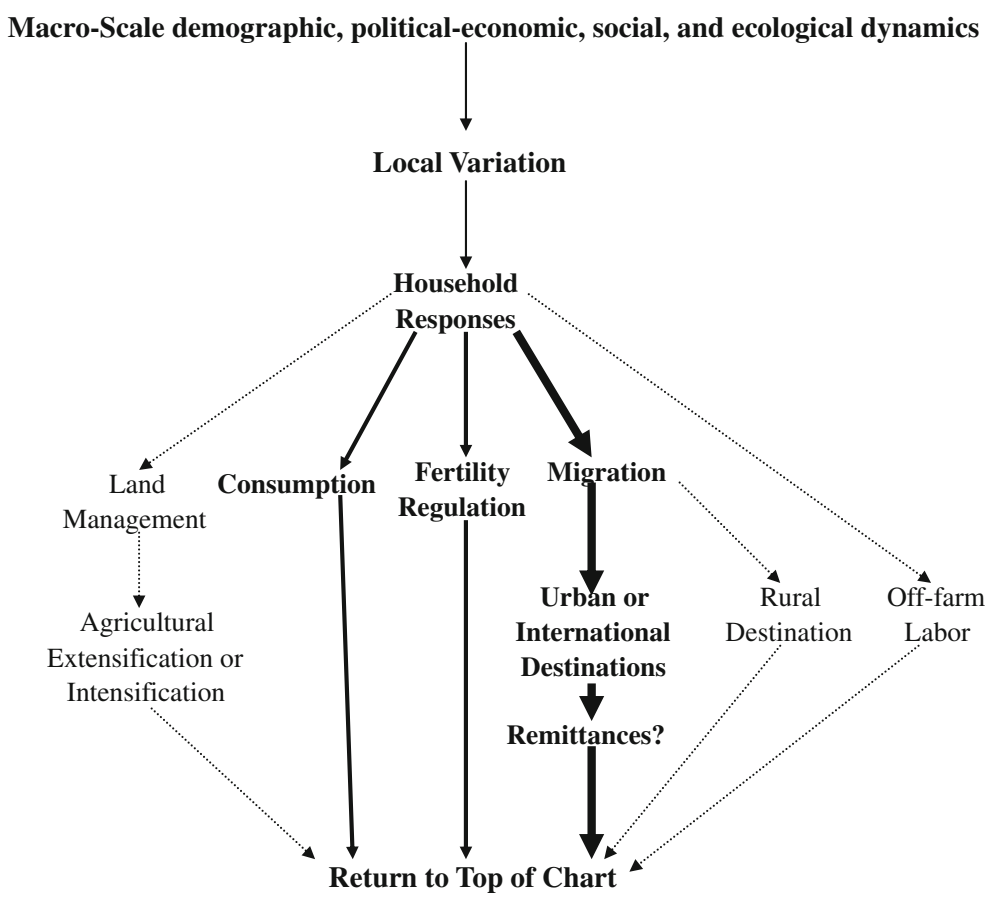

Fig. 1 Conceptual framework

become more affluent-herein attributable to remittance flows-would-be parents will balance increases in personal consumption with investments in higher "quality" children through better health care and enhanced educational attainment. These investments in child quality coupled with a reduction in child labor income, stemming from the fact that children spend more time in school, make raising children more expensive and, by extension, limit the parent's ability to increase their personal consumption. Therefore, under a quantity/quality tradeoff scenario, as households become more affluent, parents will continue to invest in children's "quality" but also reduce fertility in order to simultaneously enhance personal consumption.

Several other important factors must be considered when analyzing the migration-fertility association including socialization instincts, disruption effects, and selection effects (Rundquist and Brown 1989). A migrant's socialization instincts for wanting to mimic the fertility norms of his/her native community have been shown to be much weaker in younger migrants compared to those whose initial sojourns are later in life (Berry 1982; Findley 1982). Fertility disruption is also a common factor that accompanies migration. Both the act of migration and acclimating oneself to a new community are difficult processes that often cause migrants to delay fertility until stability can be established (Kulu 2005; Lindstrom and Saucedo 2007). Additionally, the physical separation of spouses for long 
periods of time can disrupt and negatively influence fertility (Clifford 2009). Lastly, selectivity effects are important since the ambitious nature of migrants may shape the desire for fewer children (Lindstrom 2003; Kulu 2005). Conversely, remittance income may lead to fertility reductions. Several studies have shown that increases in living standards in developing nations, particularly as related to a rise in maternal education and access to contraception, can lead to declines in household fertility rates (e.g., Heaton et al. 2005).

In this investigation, we expect international migration and the concomitant return of remittances will show a reduction in fertility through two mechanisms, the adoption of lower fertility behaviors from migrant destinations and increased socioeconomic status expressed through a quantity/quality tradeoff in numbers of children. Temporally, following migration and subsequent remittances, we anticipate immediate fertility reduction due to a change in fertility beliefs that allow for the adoption of modern contraceptive methods and an increased ability to access family planning information and to purchase contraception. We also expect sustained fertility reduction due to notions of smaller family size diffused culturally from living abroad as well as from higher socio-economic status and improved access to quality education. These are both independent factors of fertility decline that will decrease population pressures on resources vis-à-vis demographic processes.

\section{Migration, remittances, and consumption}

The circumstance that makes migration, remittances, and consumption so critical to the environment is migrants often leave areas of relatively low resource consumption to gain exposure to areas that maintain globally high rates of resource consumption. While in residence in destination areas, migrants are exposed to and often adopt local consumption patterns. In a study relating the material consumption of returning Turkish migrants who spent time in a variety of locations (Germany, Australia, North Africa, and Gulf States), Day and Içduygu (1999) found the ownership of numerous examples of conspicuous consumption (e.g., cars, cameras, refrigerators, washing machines, and watches) to be much higher in migrant households than in non-migrant households. In Latin America, while arguing over the merits of remittances as catalysts of local development, virtually all researchers of this subject agree that consumption is the predominant use of remitted income. Durand et al. (1996b) summarized over a dozen remittance studies carried out in Mexico and reported that consumption accounted for between 66 and $93 \%$ of all remittance purchases. Their own survey of 1,501 migrants in 30 Mexican communities found $76 \%$ of all remittance spending went toward consumption. To put the migration, remittances, and consumption dynamic into perspective for Guatemala-to-US migration, total primary energy consumption per capita was 20.3 times higher in the USA compared with Guatemala in 2007 (USEIA 2008). From an ecological footprint perspective that consolidates all natural resource consumption (energy, land, and water resources), the average US citizen consumes 6.3 times more resources annually compared with the average Guatemalan (WWF 2008). In this way, the potential for migration to the USA to shape Guatemalan consumption patterns holds substantial policy significance. 
We anticipate that remittance flows will lead to a net increase in resource use in general. Specifically, we anticipate an increased impact on resources by remittancereceiving households through increased consumption, first in basket necessities, such as food and clothing, and later in luxury goods and vices, such as alcoholic beverages, tobacco, and foreign consumer goods. Overall, the analyses presented below address one cycle of a multi-iterative process as households may respond (or not) to remittances by fertility regulation and changing consumption patterns.

\section{Methods}

Guatemala's western highlands provide an excellent opportunity to investigate how international migration and remittance transfers influence local environmental change because they support high levels of rural-to-international circular migration and they currently support high levels of population growth with a total fertility rate of 5.2 (De Broe and Hinde 2006). ${ }^{2}$ The combination of these factors provides a ripe opportunity to explore whether international migration and remittances alter components of environmental change-namely fertility and consumption patterns. The two case study communities (Santa Rita and Sinai) lie near Guatemala's second largest city, Quetzaltenango, and were selected for their high rates of international circular migration to the USA and associated receipts of remittance income. For the purposes of this paper, the two communities will be considered one entity as very little variation was expressed among the various attitudes and beliefs concerning fertility and consumption in response to international migration and remittances. The communities are small demographically (1,200-1,500 inhabitants) and geographically $\left(12 \mathrm{~km}^{2}\right.$ ), support high percentages of indigenous Maya (75-90\%), and contain equal percentages of Catholics and Evangelicals. Their adult literacy rates range between 40 and $70 \%$, while half of all children graduate from the sixth grade.

To determine the influence of international migration and remittances on migrantsending community lifestyle patterns, the first author conducted 89 individual interviews and one group interview in the two western Guatemalan highland communities (Fig. 2) from February to July in 2008. Through snowball sampling methods, interviews captured the opinions of eight local and regional government officials, four directors of community health care clinics, one group of 15 women, and 72 parents (43 mothers and 29 fathers). Participant observation and archival analysis complemented interview data. Informants were interviewed with a standardized survey instrument about international migration experiences, remittance transfers, and changes in fertility and consumption patterns. Interviews generally lasted 15-40 min and probed the attitudes of community members through consistent but informal, open-ended interview questions. A female Guatemalan research assistant accompanied the first author during most of the interviews to help facilitate interactions and to ease anxiety informants may have felt due to the presence of a foreign interviewer. ${ }^{3}$

\footnotetext{
${ }^{2}$ Guatemala's 2009 total fertility rate is 4.4 (PRB 2009).

3 Given the sensitive nature of some of the research topics (e.g., family planning practices), the presence of a female Guatemalan research assistant was invaluable to the interview process. This was especially
} 


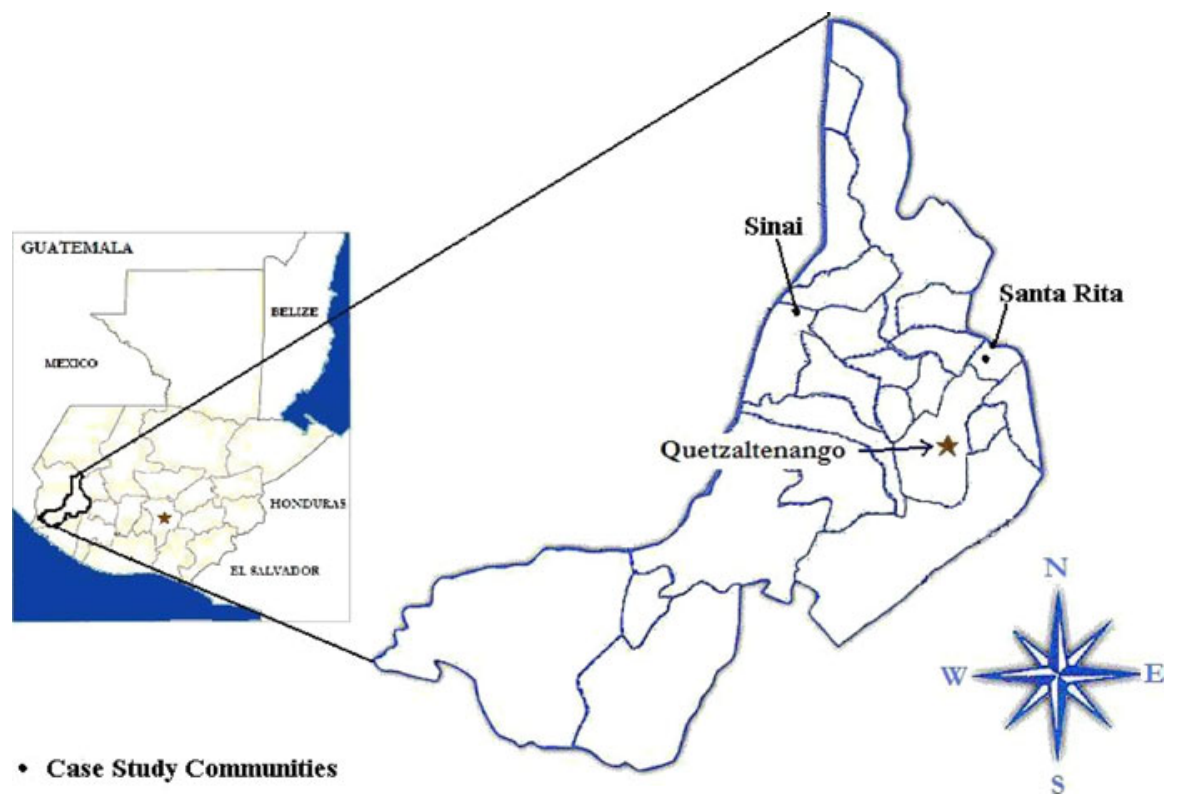

Fig. 2 Departmento de Quetzaltenango, Guatemala

\section{Results}

Migration, remittances, and fertility

To gain a sense of how international migration and remittances might influence fertility beliefs in rural Guatemalan communities, we interviewed numerous informants on a range of fertility topics. Specifically, informants were probed about their desire for more children, their knowledge, usage and attitudes toward different family planning methods, and perceived differences between the USA and local fertility norms. We also sought to determine whether exposure to the US's lower fertility culture had an influence on return migrant fertility.

One of the first subjects investigated was whether families desired to have more (or fewer) children in the future. Only 11 of 66 informants (7 from migrant-sending households) stated they wanted more children. In nearly every case, the stated reason was the high cost of child rearing. This is best illustrated by one Sinai mother, who commented la vida esta difícil ya no se consigue trabajo para poderles ganar el pan de cada día para los niños ("life is hard now, one is not able to find work to buy bread everyday for the children"). To determine whether informants

Footnote 3 continued

true when women were encountered alone, without the presence of husbands or other adults. In these situations or when there was a hint of apprehension by the informant, the primary author allowed the Guatemalan research assistant to take the lead during the interview process to provide a more comfortable situation from which to obtain more detailed and credible information. 
were taking active steps to reduce childbearing, several questions probed on the usage of contraceptive technologies.

\section{Availability and fear of birth control methods}

Modern contraception remains a controversial topic for many in rural Guatemalan communities although contraceptives were widely available at little to no cost in our study areas. Interviews with four community health care clinic directors revealed that many common birth control methods were available at all locations including birth control pills, condoms, copper-T IUDs, and Depo-Provera injections. Additionally, some of the clinics carried Norplant implants, and one clinic provided female and male sterilization operations. Three of the four clinics volunteered that they also provide information about the rhythm method. As will be further discussed below, many informants also expressed knowledge about the existence of these methods although not necessarily adopting them.

While collecting information about levels of knowledge and acceptance of contraceptive practices, numerous informants voiced concerns about the safety of modern birth control methods. Fourteen respondents, approximately $21 \%$ of those interviewed, expressed a serious health-related concern with a particular contraceptive method (Table 1). The most common stated reason for not using a particular contraceptive method was it me hace daño ("would cause me harm"). Although rarely giving personal examples, it was common to hear that hormone-based methods and IUDs could result in cancer, while female sterilization could cause premature death. Less severe side effects voiced by informants included weight gain, anxiety, headaches, and acne. Men were also discouraged from receiving vasectomies because, as Francisco, a return migrant from Santa Rita, said in English, "men in this community who get cut are called gay."

While all contraceptive methods carry potential side effects, many of the concerns voiced by the study's informants appeared to be based on myth rather than actual ill effects experienced by the informant or a partner. Only one person interviewed described actual side effects experienced while using a modern

Table 1 Views expressed about contraceptive methods

\begin{tabular}{|c|c|c|}
\hline $\begin{array}{l}\text { Contraceptive } \\
\text { method }\end{array}$ & Expressed concerns & $\begin{array}{l}\text { One informant's actual } \\
\text { experience }\end{array}$ \\
\hline $\begin{array}{l}\text { Birth control } \\
\text { pills }\end{array}$ & $\begin{array}{l}\text { Destroys the body, causes cancer, affects the nervous } \\
\text { system, causes obesity, causes acne, creates stomach } \\
\text { masses }\end{array}$ & \\
\hline $\begin{array}{l}\text { Depo-Provera } \\
\text { injection }\end{array}$ & $\begin{array}{c}\text { Damages the body, causes headaches, affects the } \\
\text { nervous system, causes obesity, causes cancer }\end{array}$ & $\begin{array}{l}\text { Eye swelling, anxiety, weight } \\
\text { gain, irritation, malaise }\end{array}$ \\
\hline Copper-T IUD & Damages the body, causes cancer & \\
\hline $\begin{array}{l}\text { Female } \\
\text { sterilization }\end{array}$ & Leads to premature death & \\
\hline Vasectomy & $\begin{array}{l}\text { Is not manly, those men who used this method are } \\
\text { considered "gay" }\end{array}$ & \\
\hline
\end{tabular}


contraceptive method-Depo-Provera injections (Table 1). The most enlightening encounter concerning this subject relates to a promotora (community health outreach worker) based in the western highlands - a person tasked with explaining which contraceptives are available, how they work, and their effectiveness. Following an extensive interview about the contraceptive methods she promoted, her response to the question "Which method do you most trust?" was Métodos naturales son mejores ("Natural methods are best"). After further inquiry, it emerged that she was among those who believed that all forms of modern contraception were harmful to women's health. She has nine children. She visits women to educate them about modern contraception but concludes her visits by warning them about unfounded harms these methods could pose to their health and advocating for "natural" methods (typically the rhythm method).

\section{US/Guatemala fertility differences}

Among the most pointed responses received while conducting the ethnographic field investigation was to the question "Why do families in the US have fewer children than families in your community?" This question was only asked after an informant stated their belief that US fertility was lower than local community fertility. An amazing array of opinions and emotions arose in response (Table 2). Informants invariably and bluntly disparaged their culture while praising the culture of the USA. Only two informants stated that they would prefer a larger family because this was the local custom. Exceptionally, one female migrant noted that she did not think that Americans liked children.

Both the Catholic and Evangelical churches were often invoked as persuasive reasons why Guatemalans have more children than Americans. ${ }^{4}$ Often, specific passages from the bible were read that supported the Church's stance against the use of most modern contraceptive methods. Yet, a 41-year-old mother of six was conflicted. On the one hand, she acknowledged the Church's proclamation that avoiding children was a sin. However, she also believed that having too many children would cause suffering for the entire family. This sentiment was expressed by a few members of the community.

\section{Does migrant household fertility differ from non-migrant household fertility?}

A variety of questions were asked to determine whether exposure to the US's lower fertility culture might be adopted and diffused back to migrant-sending households. Based on these questions, we surmise that migrant households are more apt to seek out family planning technology than non-migrant households. However, there are insufficient data to conclude with any degree of statistical certainty whether there is an actual fertility difference between the two groups. A quantitative summary of the answers to these questions follows in Table 3.

\footnotetext{
${ }^{4}$ Specific questions were asked to determine whether fertility differed between Catholic and Evangelical households. No differences were found.
} 
Table 2 Informant responses to the question "Why do families in the US have fewer children than families in your community?"

\section{Largely positive attitudes about the US}

US women work a lot and regularly use contraception

Apartments in the US are too small to house many children

Families in the US are more disciplined to properly plan a family

Americans are more civilized

Americans are more advanced

Americans are more intelligent

It costs a lot to raise a family in the US

American's do not have the time to raise children

People in the US realize that fewer children help the family save money

Americans value cars, tools, their jobs over children

Americans are much happier, life is much easier, with one child

Every country has its own culture and the US's culture does not include large families. Instead, they value work to get ahead

I think Americans do not like children

One child benefits the family. A family with just one child can raise that child to become a professional. They can better clothe and educate that child and might be able to send him/her to Harvard or to Europe

Americans receive better information

Because life is hard, Americans use birth control or limit family size while we do not have access to this information

Over there, everything costs a lot, apartments, rooms, clothes so they have 2-3 children, so they will not suffer and have to work more

They have fewer children so they can better educate their children

Negative attitudes about Guatemala

Parents here have no control

In Guatemala people don't think. They don't consider that children are expensive

We are foolish and cannot change our old ways

We know it is bad to have many children but we continue to have and have and have

Here, we are still working with hoes and raising animals while Americans are earning dollars

I think we do not comprehend the importance of family size

Families here are not paying for their children's education and medical care is free, going to the hospital is free. If families here had to pay for these things they would rethink their desire to have more children

Women in the US and in Guatemala City work. They are professionals, they work as teachers, doctors, and lawyers and do not have time to raise children. Here women work on the farm and take care of children

The mentality here is women never go to the local medical clinic even when they are pregnant. There is better education in the US

The US is superior and very advanced. We are 50-100 years behind in our development

The influence of the Church

The Church says it is bad to avoid having children

The Evangelical Church discourages talk about family planning. It is against family planning

In the bible the world of God is clear

You should not have an operation, you should not use contraception because God sends these children 


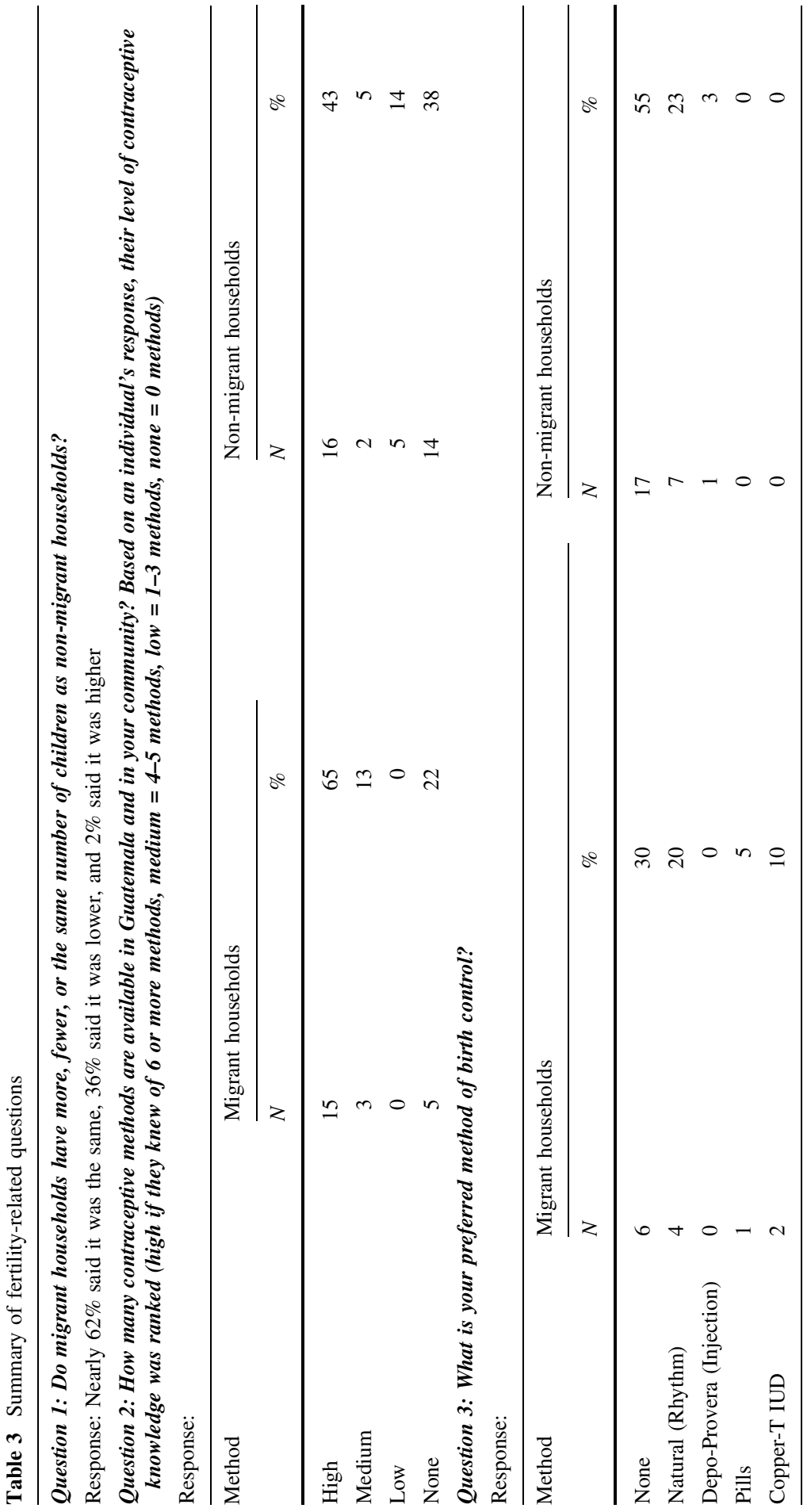




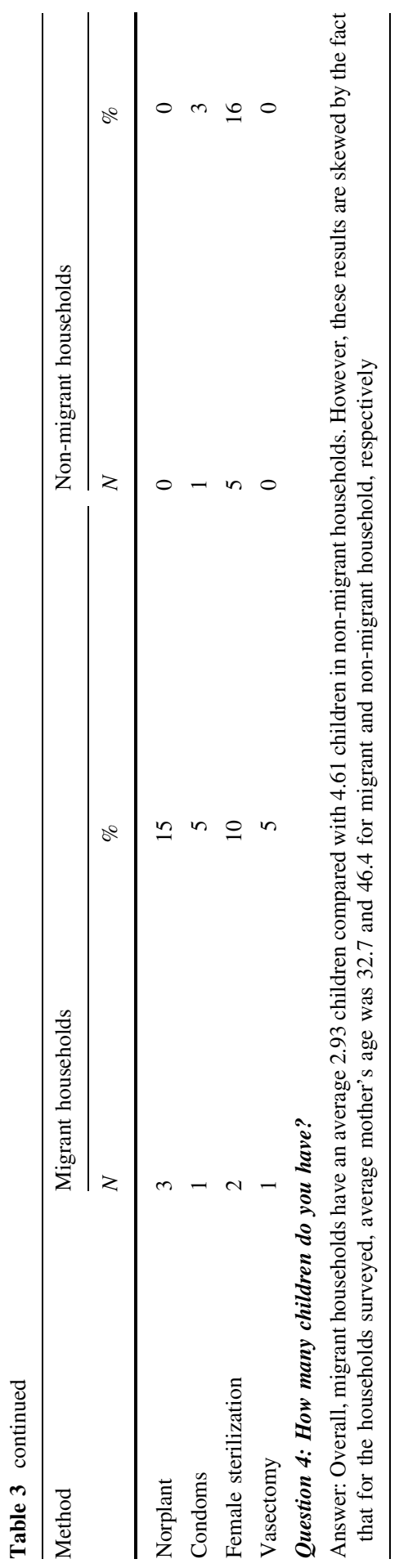


Migration, remittances, and consumption

Rural Guatemalans use international migration and remittances in many ways: to alleviate poverty, address perceived disparities in community wealth, as a way for young men to provide for a family, and as a catalyst for starting small businesses. Not all households use remittances similarly; much depends upon who receives the remittance, the household's affluence, and how long a migrant has been earning income in the USA. This section describes the conditions under which households choose particular uses for their remittances. For the purposes of this study, remittances are defined as money earned in the USA and returned to migrantsending households (wired or returned directly) or goods purchased in the USA with migrant wages and returned to sending households.

\section{Remittance uses}

As reported by $84 \%$ of all informants, new home construction was the primary motivation for most US migration (Table 4). The second and third most common uses of remittances were the purchase of household maintenance supplies and to assist with a child's education through the purchase of school supplies, uniforms, and transportation, or to pay for private school tuition. Nearly half of all informants also stated that small amounts of remittances were used to assist with agricultural operations including the purchase of soil amendments (i.e., fertilizers, pesticides) and seeds and to hire labor-principally when one or more family members were away. Remittances were also used to fund the occasional purchase of additional agricultural land. Nearly one quarter of all informants mentioned that migrantsending households use remittances to launch small businesses and to purchase automobiles.

A host of conspicuous consumption purchases were also reported including household appliances (i.e., refrigerators, washing machines), furniture, and

Table 4 Reported remittance use by 86 informants

\begin{tabular}{|c|c|c|}
\hline Type of use & $N$ & $\%$ \\
\hline Home construction or improvement & 72 & 84 \\
\hline $\begin{array}{l}\text { Household maintenance purchases (food, clothes, power, } \\
\text { gas, water, medicine) }\end{array}$ & 48 & 56 \\
\hline $\begin{array}{l}\text { Assistance to children's education (computers, school } \\
\text { supplies, transportation, tuition for private schools and } \\
\text { colleges, uniforms) }\end{array}$ & 48 & 56 \\
\hline $\begin{array}{l}\text { Agricultural purchases (fertilizers, labor, land, mechanized } \\
\text { equipment, pesticides, seeds) }\end{array}$ & 39 & 45 \\
\hline Small business investments & 22 & 26 \\
\hline Vehicle purchases & 21 & 24 \\
\hline $\begin{array}{l}\text { Non-essential item purchases (refrigerator, washing } \\
\text { machine, television, stereo, video games, cable, Internet, } \\
\text { furniture, computer, cell phone, fiestas) }\end{array}$ & 12 & 14 \\
\hline Debt repayment & 6 & 7 \\
\hline
\end{tabular}


entertainment equipment (i.e., cable, cell phones, computers, Internet, stereos, and televisions). One Sinai informant stated that his brother annually sends money to pay for the community's la Navidad (Christmas) festivities. While not asked directly, seven percent of informants also listed debt repayment as a primary use of remittances.

\section{Differential migrant-sending household aspirations}

Two important factors help explain patterns of remittance use by migrant-sending households: (1) demographic/economic characteristics and (2) life stage of remittance recipient. For instance, several male migrant returnees who had left for the USA as young (15-19 years old), single adults stated that for them, migration fulfilled two purposes. First, migration was an important rite of passage, and second, it provided a means to earn and save sufficient money to eventually return and build a home in their native communities. The second objective was undertaken with the intention of enticing prospective brides. A similar dynamic was reported for Mexico by Conway and Cohen (1998).

A second sizeable group of remittance earners/receivers was young, married couples who either migrated together or sent one member abroad. Given the high levels of poverty and land scarcity, this group used international migration as a means to establish themselves economically. In these cases, money was sent home to cover household maintenance expenses (food, clothes, and medicine) and was saved to eventually purchase a small plot of land to build a house with an adjoining subsistence farm plot. Additionally, these families used some remittance money to send children to school.

We identified a third category of migrants who were older and more establishedthey typically owned a home and had a small plot of agricultural land. This group used migration to either jumpstart a small business or to improve their community standing by using remittances to construct a more modern house, buy a newer car, and/or expand agricultural land ownership. For these households, international migration was a means to diversify their income portfolio and/or to respond to feelings of relative deprivation by improving their perceived wealth status.

The last group of remittance receivers represented non-nuclear family members (parents, sisters, brothers, cousins, etc.). For this group, remittances were largely received infrequently and in small amounts. An older Sinai couple with two daughters in the USA stated using remittances principalmente para comprar nuestras comidas porque aquísolo maíz tenemos ("principally to buy food because we only grow corn"). In addition to food purchases, remittance gifts were disproportionally used to supplement household expenses including clothing and medicine purchases or to pay utility bills.

\section{Discussion}

To better understand the environmental impact of migration and concomitant remittance transfer, it is useful to explore tradeoffs between changes in consumption and fertility. For instance, does increased affluence and exposure to a culture with 
lower fertility norms lead to the adoption of these norms thus creating a situation where a rise in material consumption is counterbalanced by a decline in household size? These dynamics are critical for the vast numbers of individuals and families directly and indirectly influenced by economic migration. Additionally, they shed light on the future condition of multitudes of rural poor who strive to increase their standards of living in an era of globalization. Within our rural western Guatemalan case study communities, economic migration does not beget a balanced environmental checkbook. Given modest reductions in fertility and immediate increases in remittance-induced consumption, we conclude that successful economic migration on balance will lead to more (dispersed) natural resource use rather than less. As expected, remittance-receiving households escalated consumption, new home construction was the most cited and substantial use of remittances, but remittances were also used to cover basic subsistence living expenses and to supplement costs associated with children's education and farming activities. While living standards in Guatemala remain modest compared with the USA even after successful migration journeys, the difference in the levels of material comfort between successful migrant-sending households and the average non-migrant household was striking. Unlike their non-migrant counterparts, migrants often returned to newly constructed, multistoried, concrete houses that dwarfed the modest adobe houses of non-migrant neighbors. Furthermore, the most successful migrants often displayed their newly begotten wealth through conspicuous purchase of automobiles, cell phones, modern appliances, and video games.

While this investigation was not designed to provide robust empirical findings concerning differential fertility between migrant and non-migrant households, the information gathered suggests that exposure to the US's lower fertility culture allows migrant-sending households to better achieve their desired fertility. Evidence for this derives from their better knowledge, acceptance, and elevated use of more effective birth control methods including IUDs and hormonal methods. We believe the results would have been even more definitive if we had found more return female migrants. Other studies suggest that male migrants require a substantial amount of time in residence before they begin to adopt and diffuse the US's lower fertility norms (Lindstrom and Saucedo 2002; Davis in press). In contrast, female migrants have been shown to adopt the US's lower fertility habits immediately upon arrival and maintain this lower desired fertility mentality after returning to their native communities.

The totality of the fertility responses, when combined with the information gathered about consumption, lead us to conclude that most Guatemalans strive to achieve US living standards by increasing consumption immediately although less inclined to substantially reduce fertility. Even so, parental attitudes toward fertility and consumption appear to be moving toward a "quantity/quality" tradeoff where parents attempt to balance personal consumption with fewer children but higher investments in the children's' human capital. This conclusion is largely based on informant responses detailed in Table 2 about perceived differences between US and Guatemala family sizes. It is clear from these responses that Guatemalan parents believe that having fewer children leads to human capital enhancements for all family members as well as increased personal consumption. Yet, rampant 
misinformation about the safety of contraceptives appears to weaken parent's ability to manage fertility with modern birth control methods.

The stubbornly slow rise in contraceptive knowledge witnessed in this investigation, especially among non-migrants, may be attributable to numerous popular myths concerning the safety of modern contraceptive methods. Such myths were evident even in a few younger as well as migrant-sending households. Additionally, while most informants stated they did not want additional children, $45 \%$ were not using birth control (including the rhythm method) to prevent further conceptions. Even so, informant communities were within a 25-minute bus ride of a government-run health clinic providing free modern contraception. Such low levels of birth control can be attributed to the primary source of official knowledge being unsupportive of contraceptive use among rural Guatemalan communities. In addition, there is a high unmet need for accurate contraceptive information.

While we believe that the rise in material consumption attributable to migration and remittances will outpace any decline attributable to the adoption of lower fertility norms, we are not suggesting that the average Guatemalan migrant will immediately increase his/her consumption to a level equivalent to the average person residing in the USA. However, evidence collected during this study indicates that consumption patterns do increase immediately and substantially with the receipt of remittance income. From an environmental preservation standpoint, it does not appear that this immediate increase in resource consumption can be counterbalanced now or in the future by a subsequent decline in fertility. Essentially, as Guatemalans strive to achieve the living standards of the USA, we believe they will endeavor to equal current US consumption rates, which are currently 6-20 times higher than existing Guatemalan levels. At best, if they achieve US fertility levels, fertility will decline from a current average of 5.2 children per women to 2.1. On the plus side for Guatemalan migrant-sending communities, the environmental harms associated with a sharp rise in consumption will not be fully felt at home. Much of these harms will occur in other parts of the planet where the raw materials for items of conspicuous consumption are extracted, processed, packaged, and transported, eventually reaching Guatemala for their use and disposal.

While this investigation identifies important community-specific environmental effects, it also provides evidence for more global trends. In essence, Guatemalan migrants who are exposed to the more develop economies act as indicators for a future rise in resource consumption throughout the developing world. As LDCs strive to achieve the living standards of the developed world, their consumption levels are likely to rise substantially while not being fully mitigated by a concomitant drop in fertility levels. Such prognoses, should they come to fruition, will make it increasingly difficult for global nations to reduce harms associated with consumption of natural resources including global climate change.

\section{Conclusion}

While successful Guatemala-US economic migrants are increasing material consumption, household fertility levels remain high. While many informants 
identify investments in human capital (children's education and health care) and small businesses as common uses of remitted income, almost every informant, first and foremost, mentioned the construction of a new home as the preeminent use of remittances. This finding contradicts our expectations that households would invest first in basic household necessities, suggesting that the economic conditions for interviewed international migrant households had reached a sufficient level of affluence where the demand for basic necessities had been met. As reflected in Table 4, desires to obtain items of conspicuous consumption now pull individuals to international destinations.

Evidence supports our conceptual model generally while providing considerations for its further refinement. For example, growth of material consumption may be partially counterbalanced by the adoption of family planning in origin households following migration. While we do not have tangible proof, we believe that increased contraceptive knowledge, acceptance, and usage of family planning technology by migrants will diffuse slowly throughout sending communities upon their return. And, this dynamic will have a long-term negative influence on local fertility trends leading to a concomitant decline in natural resource consumption. However, we maintain our belief that economic migration will continue to promote a rise in natural resource use in the long term.

The unmet need for contraceptive knowledge, particularly as it relates to dispelling myths concerning the safety and proper use of modern family planning methods, is a ripe opportunity for family planning professionals. Enhancing access and acceptance would allow families to achieve desired levels of fertility while also providing positive environmental benefits. Reeducating community promotoras and providing more community charlas (informational meetings) to dispense factual contraceptive knowledge are obvious needs to be met by local, regional, and national Guatemalan governmental agencies and/or family planning professionals. Additionally, for non-governmental organizations in the USA or other migration destination areas, great benefit can be derived from instituting programs that dispense accurate contraceptive information in areas of high migrant concentration. Particularly for female migrants, evidence from this study as well as others (Lindstrom and Saucedo 2002; Davis in press) suggests migrant women are particularly open and desiring of information on family planning.

This research has conceptualized and observed household consumption and fertility responses to remittances in a developing world context. Future research may pursue such queries in other settings. Ultimately, if cross-national patterns emerge through further research, socio-ecological theory can be advanced to better reflect these associations of critical importance to both human and environmental sustainability.

Open Access This article is distributed under the terms of the Creative Commons Attribution Noncommercial License which permits any noncommercial use, distribution, and reproduction in any medium, provided the original author(s) and source are credited. 


\section{References}

Adamo, S. B. (2010). Environmental migration and cities in the context of global environmental change. Current Opinion in Environmental Sustainability, 2(3), 161-165.

Adams, R. (2004). Remittances and poverty in Guatemala. World Bank Policy Research, Working Paper no. 3418. Washington, DC: World Bank.

Adams, R. (2006). International remittances and the household: Analysis and review of global evidence. Journal of African Economics, 15, 396-425.

Adams, R., \& Page, J. (2005). Do international migration and remittances reduce poverty in developing countries?. Washington, DC: World Bank.

Allen, J. C., \& Barnes, D. F. (1985). The causes of deforestation in developing countries. Annals of the American Association of Geographers, 75, 163-184.

Becker, G. S. (1992). Fertility and the economy. Population Economics, 5(3), 185-201.

Berry, H.E. (1982). Migration, fertility and development: a conceptual note and proposal for research in Ecuador. In Studies on the interrelationship between migration and development in third world settings, Discussion Paper 3. Columbia, OH: Department of Geography, The Ohio State University.

Bilsborrow, R. E. (1987). Population pressures and agricultural development in developing countries: A conceptual framework and recent evidence. World Development, 15, 183-203.

Brockett, C. D. (1988). Land, power, and poverty: Agrarian transformation and political conflict in Central America. Winchester, MA: Allan and Unwin, Inc.

Camlin, C. S., Hosegood, V., Newell, M., McGrath, N., Bärnighausen, T., et al. (2010). Gender, migration and HIV in rural KwaZulu-Natal, South Africa. PLoS ONE, 5(7), e11539. doi:10.1371/journal. pone.0011539.

Carr, D. L. (2004). Proximate population factors and deforestation in tropical agricultural frontiers. Population and Environment, 25(6), 585-612.

Carr, D. L. (2008). Farm households and land use in a core conservation zone of the Maya Biosphere Reserve, Guatemala. Human Ecology, 36(2), 231-248.

Carr, D. L. (2009). Migration and tropical deforestation: Why population matters. Progress in Human Geography, 33(9), 355-378.

Carr, D. L., Lopez, A. C., \& Bilsborrow, R. E. (2009). The population, agriculture, and environment nexus in Latin America: country-level evidence from the latter half of the 20th century. Population and Environment, 30, 222-246.

Carr, D. L., Suter, L., \& Barbieri, A. (2006). Population dynamics and tropical deforestation: State of the debate and conceptual challenges. Population and Environment, 27(1), 89-113.

Clifford, D. (2009). Spousal separation, selectivity and contextual effects: Exploring the relationship between international labour migration and fertility in post-Soviet Tajikistan. Demographic Research, 21, 945-975.

Conway, D., \& Cohen, J. H. (1998). Consequences of migration and remittances for Mexican transnational communities. Economic Geography, 74(1), 26-44.

Daily, G. C., \& Ehrlich, P. R. (1992). Population, sustainability, and Earth's carrying capacity. BioScience, 42, 761-771.

Davis, K. (1963). The theory of change and response in modern demographic history. Population Index, 29, 345-366.

Davis, J. (2006). Remittances and agricultural change in Central America and the Caribbean. Global Development Studies, 4(3-4), 117-131.

Davis, J. (in press). Decoupling migration effects from income effects on reproduction in Central American migrant-sending households. International Migration Review.

Day, L. H., \& Içduygu, A. (1999). Does international migration encourage consumerism in the country of origin?-a Turkish study. Population and Environment, 20(6), 503-525.

De Broe, S., \& Hinde, A. (2006). Diversity in fertility patterns in Guatemala. Population, Space and Place, 12, 435-459.

Durand, J., Kandel, W., Parrado, E. A., \& Massey, D. S. (1996a). International migration and development in Mexican communities. Demography, 33(2), 249-264.

Durand, J., Parrado, E. A., \& Massey, D. S. (1996b). Migradollars and development: A reconsideration of the Mexican case. International Migration Review, 30(2), 423-444.

Findley, S. E. (1982). Fertility and migration. In International encyclopedia of population, New York. 
Findley, S. E. (1994). Does drought increase migration? A study of rural migration from Mali during the 1983-1985 drought. International Migration Review, 28, 539-553.

Geist, H. J., \& Lambin, E. F. (2002). Proximate causes and underlying driving forces of tropical deforestation. BioScience, 52(2), 143-150.

Gray, C. (2009). Rural out-migration and smallholder agriculture in the southern Ecuadorian Andes. Population and Environment, 30(4), 193-217.

Heaton, T. B., Huntsman, T. J., \& Flake, D. F. (2005). The effect of status on women's autonomy in Bolivia, Peru and Nicaragua. Population Research and Policy Review, 24(3), 283-300.

House, K. L. (1999). Absent ones who are always present: migration, remittances, and household survival strategies in Guatemala. M.A. Thesis, Department of Geography, Queen's University at Kingston, Canada.

IMF (International Monetary Fund). (2008). Balance of payment statistics yearbook. Washington, DC.

IOM (International Organization for Migration). (2008). Survey on remittances 2008 and the environment. Geneva, Switzerland: International Organization for Migration.

Jokisch, B. D. (2002). Migration and agricultural change: The case of smallholder agriculture in highland Ecuador. Human Ecology, 30(4), 523-550.

Kanaiaupuni, S. M., \& Donato, K. M. (1999). Migradollars and mortality: The effects of migration on infant survival in Mexico. Demography, 36(3), 339-353.

Kandel, W., \& Kao, G. (2001). The impact of temporary labor migration on Mexican children's educational aspirations and performance. International Migration Review, 35(4), 1205-1231.

Kane, H. (1995). The hour of departure: Forces that create refugees and migrants. Worldwatch Paper 125, Washington, DC: Worldwatch Institute.

Kates, R. W. (2000). Population and consumption: What we know, what we need to know. Environment, 42(3), 10-19.

Kitzes, J., Wackernagel, M., Loh, J., Peller, A., Goldfinger, S., Cheng, D., et al. (2008). Shrink and share: Humanity's present and future Ecological Footprint. Philosophical Transactions of the Royal Society of London. Series B, 363, 467-475.

Kulu, H. (2005). Migration and fertility: Competing hypotheses re-examined. European Journal of Population, 21, 51-87.

Lindstrom, D. P. (2003). Rural-urban migration and reproductive behavior in Guatemala. Population Research and Policy Review, 22, 351-372.

Lindstrom, D. P., \& Saucedo, S. S. (2002). The short- and long-term effects of US migration experience on Mexican women's fertility. Social Forces, 80(4), 1341-1368.

Lindstrom, D. P., \& Saucedo, S. S. (2007). The interrelationship between fertility, family aintenance, and Mexico-US migration. Demographic Research, 17(28), 821-859.

Lonergan, S. (1998). The role of environmental degradation in population displacement. Environmental Change and Security Project Report, 4, 5-15.

Lovell, W. G. (1995). A beauty that hurts: Life and death in Guatemala. Austin, TX: University of Texas Press.

Manz, B. (2004). Paradise in ashes: A Guatemalan journey of courage, terror, and hope. Berkeley, CA: University of California Press.

Massey, D. S., Arango, J., Hugo, G., Kouaouci, A., Pellegrino, A., \& Taylor, J. E. (1993). Theories of international migration: A review and appraisal. Population and Development Review, 19(3), 431-466.

Mather, A. S., \& Needle, C. L. (2000). The relationship of population and forest trends. Geographical Journal, 166, 2-13.

Moore, E., \& Smith, J. (1995). Climatic change and migration from Oceania: Implications for Australia, New Zealand and the United States of America. Population and Environment, 17(2), 105-122.

Moran, E. (1993). Deforestation in the Brazilian Amazon. Human Ecology, 21(1), 1-21.

Moran-Taylor, M. J. (2008). Guatemala's Ladino and Maya migra landscapes: the tangible and intangible outcomes of migration. Human Organization, 67, 111-124.

Morrison, A. R. (1993). Violence or economics: What drives internal migration in Guatemala? Economic Development and Cultural Change, 41(4), 817-831.

Panayatou, T. (1994). The population, environment, and development nexus. In R. Cassen (Ed.), Population and development: Old debates, new conclusions. Washington, DC: Overseas Development Council.

PRB (Population Reference Bureau). (2009). 2009 World population data sheet. Washington, DC: Population Reference Bureau. 
Rees, W. E., \& Wackernagel, M. (1994). Ecological footprints and appropriated carrying capacity: Measuring the natural capital requirements of the human economy. In A. M. Jansson, H. Hammer, C. Folke, \& R. Costanza (Eds.), Investing in natural capital: The ecological economics approach to sustainability. Washington, DC: Island Press.

Rosero-Bixby, L., \& Palloni, A. (1998). Population and deforestation in Costa Rica. Population and Environment, 20(2), 149-185.

Rundquist, F., \& Brown, L. A. (1989). Migrant fertility differentials in Ecuador. Geogrfiska Annaler, $71 B(2), 109-123$.

Smith, J. (2006). Guatemala: Economic migrants replace political refugees. Washington, DC: Migration Policy Institute. http://www.migrationinformation.org/feature/display.cfm?ID=392. Cited May 1, 2010.

Taylor, J. E. (1999). The new economics of labour migration and the role of remittances in the migration process. International Migration, 37(1), 63-88.

Taylor, M. J., Moran-Taylor, M. J., \& Ruiz, D. R. (2006). Land, ethnic, and gender change: Transnational migration and its effects on Guatemalan lives and landscapes. Geoforum, 37(1), 41-61.

Turner, B. L., I. I., \& Ali, S. (1996). Induced intensification: Agricultural change in Bangladesh with implications for Malthus and Boserup. Proceeding of the National Academy of Sciences, 93, 14984-14991.

UN (United Nations). (1998). Human development report: Consumption for human development. New York: United Nations Development Programme.

UN (United Nations). (2009). Human development report: Overcoming barriers: human mobility and development. New York: United Nations Development Programme.

USEIA (United States Energy Information Administration). (2008). Washington, DC: International Energy Statistics, Department of Energy. http://tonto.eia.doe.gov/cfapps/ipdbproject/iedindex3. $\mathrm{cfm}$ ?tid=44\&pid=45\&aid=2\&cid=\&syid=2003\&eyid=2007\&unit=QBTU\#. Cited May 12, 2010.

WWF (World Wildlife Fund). (2008). Living planet report 2008. Gland, Switzerland: WWF International. 